\title{
COMBINED CHEMICAL-BIOLOGICAL TREATMENT OF EFFLUENTS FROM SOIL REMEDIATION PROCESSES BY SURFACTANTS SOLUTIONS FLUSHING
}

\author{
CHEMICZNO-BIOLOGICZNE OCZYSZCZANIE ŚCIEKÓW \\ POWSTAJĄCYCH PODCZAS OCZYSZCZANIA ZAOLEJONYCH GRUNTÓW \\ ROZTWORAMI SURFAKTANTÓW
}

\begin{abstract}
In recent years combined chemical-biological wastewater treatment processes have received increasing interest. In the present study wastewater from soil remediation processes were treated by means of 1-step processes like Fenton, aerobic degradation and 2-steps combined method. The effluents resulting from soil remediation processes consist of high surfactant concentration solutions, mobilized oils and oil-in-water $(\mathrm{o} / \mathrm{w})$ emulsions. The effectiveness of wastewater treatment was evaluated by COD reduction and surfactant removal. The application of Fenton process alone showed around $80 \%$ of COD and surfactant removal, and in case of aerobic process only $60 \%$ of COD and $50 \%$ of surfactant removal was accomplished. However, the maximum COD reduction and surfactant removal from wastewater samples, above $90 \%$, was obtained in aerobic degradation with Fenton process as pretreatment. Thus, the Fenton process could be effectively applied as a pretreatment step to improve the reduction of both COD and surfactant from wastewater resulting from soil remediation.
\end{abstract}

Keywords: aerobic treatment, Fenton treatment, non-ionic surfactant, o/w emulsion, PAO6 oil, soil remediation

Contamination of soil by petrochemical products and their derivatives is widespread and frequent due to their common use as eg fuels, heating mediums, lubricants, drawing oils, etc. One of the methods of soil remediation is flushing of contaminated soil by surfactants solutions. This method can be used on the site of the oil spill or accident (in-situ) but also outside of the remediation site (ex-situ). Surfactants in soil remediation are used to improve contaminated aquifer remediation rates. Principal remediation mechanisms include micellar solubilization and mobilization of the trapped liquids by lowering of the oil/water interfacial tension $[1,2]$. By reducing the interfacial tension surfactants can also stabilize the emulsion and decreasing the rate of coalescence [3].

\footnotetext{
${ }^{1}$ Chemical Faculty, Gdansk University of Technology, ul. G. Narutowicza 11/12, 80-233 Gdańsk, Poland, phone +48583472349, fax +48583486278

* Corresponding author: elzbieta.hallmann@pg.gda.pl
} 
The process of soil remediation by surfactant solution flushing requires great amounts of water, therefore it results in vast quantities of wastewater. The effluents resulting from these processes consist of high surfactant concentration solutions, mobilized contamination and oil-in-water (o/w) emulsions. Such a constitution of wastewater makes them difficult to treat in standard biological methods. Several methods for oils and surfactants removal from wastewater are used but not if they are present in emulsified form. Mobilized oil can be separated from the aqueous phase in the wastewater by physical methods, as a result, separate streams of free oil and water that are nearly oil-free are produced. Wastewater which contains surfactant solution and the stabilized o/w emulsion should be cleaned further via a series of treatment steps. In the case of high surfactant concentration in o/w emulsions it is important to find a treatment method that is efficient both for surfactant and oil removal.

Great number of surfactant agents is not easily biodegradable [4]. One of the methods for the surfactants treatment are the bacteria for example in activated sludge. On the other hand, surfactants are toxic for the living microorganisms. For a biological treatment, the surfactant concentration in the medium cannot exceed $1000 \mathrm{mg} / \mathrm{dm}^{3}$ due to its toxicity toward microorganisms and foaming in aerated bioreactors [5]. High concentrations of surfactants may limit biological processes due to the toxicity of some synthetic surfactants and their intermediate metabolites. As far as type of surfactant is concerned, it was found that during an aerobic treatment the removal of anionic surfactants from wastewater is greater than non-ionic surfactants removal during similar process [6].

Therefore, many methods of pretreatment such as the Fenton reaction and other techniques of advanced chemical oxidation were developed to eliminate surfactants. Fenton process is an advanced oxidation technology (AOP) in which a mixture of hydrogen peroxide and iron(II) salts is added directly to the wastewater. The process is based on the formation of reactive oxidizing species, able to efficiently degrade the pollutants of the wastewater stream [7]. Besides the oxidation carried out by the hydroxyl radicals the removal of pollutants is also promoted by coagulation and sedimentation. This AOP has been largely studied and good efficiency is reported for the treatment of wastewaters polluted with different organics [8,9]. Fenton reaction was also successfully applied to wastewater consisted only of surfactants $[10,11]$ as well as to real effluents from different resources like chemical or pharmaceutical manufacturers [12, 13]. It should be mentioned that complete mineralization is usually not a final goal in either water or wastewater treatment. Mostly, in wastewater treatment, the improvement of biodegradability is a crucial achievement, especially for surfactants and oil rich effluents that are commonly resistant to biological treatment.

In recent years combined chemical-biological wastewater treatment process have received increasing interest. Combined method starts with biological step unless there are highly toxic compounds. In recycle systems overdosing of the oxidative agents can even be harmful for a biological process. Hydrogen peroxide is usually not critical because of its relatively low toxicity for bacteria and because of cleaving hydrogen peroxide into water and oxygen [14]. Combined chemical biological oxidation processes can provide effective and economic solutions.

The objective of this research was the treatment of the effluents resulting from the soil remediation processes. The process was carried out at first stage by means of 1-step Fenton process and single aerobic degradation. At a later stage, by means of a combined treatment, 
with a Fenton pretreatment followed by an aerobic degradation stage. In both cases, the objectives are to report data for the removal of the wastewater components such as oil and surfactant, represented by the decrease of the chemical oxygen demand (COD) and surfactant concentration (NL6).

\section{Experimental}

\section{Materials}

Synthetic base oil, PAO6 (polyalfaolefine, Lotos S.A., Poland) was selected as hydrophobic pollutant. PAO6 is synthetic base oil, obtained by polimerization of 1-decene (for a viscosity of $6 \mathrm{~mm}^{2} / \mathrm{s}$ at $100^{\circ} \mathrm{C}$ ). Surfactant used was Rokanol NL6 $\left(\mathrm{C}_{9-11} \mathrm{H}_{19-21}\left(\mathrm{OCH}_{2} \mathrm{CH}_{2}\right)_{6} \mathrm{OH}\right)$ synthetic non-ionic surfactant. Rokanol NL6 was obtained from PCC Rokita S.A. (Brzeg) and it is polydisperse mixture of polyethoxylated alcohols. Some of physicochemical properties of investigated surfactant were presented elsewhere [15]. All chemicals were of reagent grade, or analytical grade when available, and were used without further purification. Stock solutions were prepared in double-distilled water.

\section{Emulsion preparation}

The preparation of oil-in-water emulsions was performed according to the following procedure: $15 \mathrm{~g}$ of PAO6 oil $(3 \% \mathrm{w} / \mathrm{w})$ was added to an Erlenmeyer flask containing $500 \mathrm{~cm}^{3}$ aqueous solution of surfactant Rokanol NL6. The oil was dispersed in surfactant solution using a IKA HS 260 shaker. The emulsion from the flask was carefully transferred to the separation funnel and allow to stand for two days. After that time the oil phase was separated and the residual phases (emulsion and water phase) were regarded as wastewater in Fenton and aerobic processes. Separation of the oil phase was motivated by practical and economical issues due to reduced COD value of the wastewater and simplifying the treatment process. In practice free or suspended oil can be separated from the aqueous phase in the oil wastes by different gravity-based settling methods. The concentration of surfactant solutions in the emulsion were in the range from 1 to $5 \mathrm{~g} / \mathrm{dm}^{3}$.

\section{Fenton process}

Samples $\left(400 \mathrm{~cm}^{3}\right)$ were treated with permanent agitation speed $(400 \mathrm{rpm})$ for a period of $1 \mathrm{~h}$. The catalyst (ferrous iron as $\mathrm{FeSO}_{4} \cdot 7 \mathrm{H}_{2} \mathrm{O}$ ) was added first and the reaction was subsequently initiated by adding $\mathrm{H}_{2} \mathrm{O}_{2}$ (as $30 \%$ solution) stepwise. The weight ratio of $\mathrm{H}_{2} \mathrm{O}_{2} / \mathrm{Fe}^{2+}$ was kept invariable at $6: 1$, which is the optimal ratio of hydrogen peroxide to ferrous ions [16]. Oxidation experiments were carried out without $\mathrm{pH}$ regulation. The oxidation was terminated by the adjustment of samples $\mathrm{pH}$ to $9 \div 11$ by adding 1 or $5 \mathrm{M}$ of $\mathrm{NaOH}$. After precipitation of iron hydroxycomplexes the samples were kept for a period of 1-2 hours to allow solids to settle. The supernatant was decanted and filtered and then analyzed for COD and for surfactant Rokanol NL6 concentration. It should be noted that hydrogen peroxide applied in the Fenton oxidation process can partly remain in oxidized wastewater samples. The residual $\mathrm{H}_{2} \mathrm{O}_{2}$ can interfere with $\mathrm{COD}$ measurement by reduction of potassium dichromate used as an oxidant in the standard COD test. For that reason, the COD measurements in the present study were performed only after the Fenton processes. 
Increase of $\mathrm{pH}$ to basic values, as it is done for the initiation of iron(III) precipitation, leads to hydrogen peroxide autodecomposition into oxygen and water [17].

The experiments were duplicated and performed at ambient room temperature $\left(23^{\circ} \mathrm{C}\right)$.

\section{Aerobic process}

The effluents, either after physical separation or Fenton pretreatment, was placed into a laboratory reactor (volume of $2 \mathrm{dm}^{3}$ ) with activated sludge and biological treatment was performed at continuous stirring and aeration. Activated sludge was taken from nitrification chamber in the municipal WWTP Gdansk WSCHOD. The suspended solids content was $6 \mathrm{~g} / \mathrm{dm}^{3}$. In the experiment the activated sludge loading was $0.12 \mathrm{~g}$ COD/g MLSS. The process was conducted for 6 hours, as it is the typical duration of biological process for municipal wastewater. The samples for COD (every 30 minutes) and surfactant (every $180 \mathrm{~min}$ ) tests were taken directly from the reactor, filtered and analyzed. The experiments were triplicated and performed at ambient room temperature $\left(23^{\circ} \mathrm{C}\right)$.

\section{Analytical procedures}

The COD was determined by dichromate method. The non-ionic surfactant concentration was determined by spectrophotometric (Varian Cary 50 UV/VIS) method using Dragendorff's reagent (according to the Polish norm). Dragendorff's reagent (iodobismuthate) was used to determine polyethoxylated surfactants because it forms an insoluble orange stoichiometric complex with polyethylene glycols.

The results of the analysis of wastewater and of the samples from treatment experiments are presented as the mean value $(n=3)$ whereas the standard deviation was $\leq 2.5 \%$ in all cases.

\section{Wastewater characterization}

The standard emulsion samples used in our research were effluents after soil remediation with initial $1 \mathrm{~g} / \mathrm{dm}^{3}$ Rokanol NL6 concentration. Effluents after physical separation of oil phase were considered as wastewater for further investigations. So the wastewater consisted of surfactant solution and stabilized o/w emulsion. The COD of such wastewater was around $3000 \mathrm{mg} \mathrm{O} / \mathrm{dm}^{3}$ and the $\mathrm{pH}$ value was 5 .

In case of some 1-step Fenton processes higher surfactant concentration were used. The COD of such wastewaters were 4500, 5500, 8000 and $10000 \mathrm{mg} \mathrm{O}_{2} / \mathrm{dm}^{3}$ for 2, 3, 4, $5 \mathrm{~g} / \mathrm{dm}^{3}$ Rokanol NL6 initial concentration, respectively. The wastewater were not diluted, even in case of high surfactant concentration.

\section{Results and discussion}

\section{Fenton process 1-step}

The Fenton process was performed without $\mathrm{pH}$ adjustment to acidic 3 values, as it is required for the classical Fenton reaction. From the very beginning of the oxidation, a rapid decrease of wastewater $\mathrm{pH}$ was observed (approximately $\mathrm{pH} 2 \div 3$ ), most likely because of acidic by-products formation. 


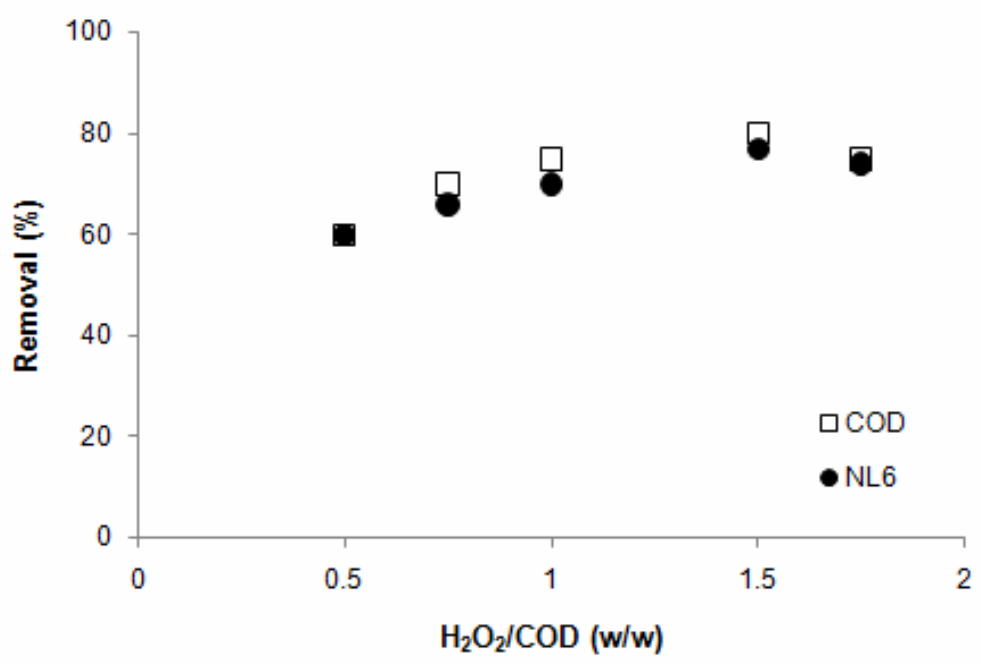

Fig. 1. Removal of COD and NL6 versus $\mathrm{H}_{2} \mathrm{O}_{2} / \mathrm{COD}$ weight ratio for Fenton system at $1 \mathrm{~g} / \mathrm{dm}^{3}$ surfactant initial concentration

In Figure 1 the variations of COD and NL6 with the amount of hydrogen peroxide supplied in the Fenton oxidation treatment are shown. The COD values are proportional to the content of both components, while NL6 concentration presents the content of surfactant. Experiments were conducted to examine the effect of the $\mathrm{H}_{2} \mathrm{O}_{2} / \mathrm{COD}$ weight ratio on the percent COD and surfactant removal. For higher oxidant dosages, increased percent of surfactant removals were observed. At $\mathrm{H}_{2} \mathrm{O}_{2} / \mathrm{COD}$ weight ratio greater than 1.5 , less surfactant removal was observed, the reason for this may have been scavenging of hydroxyl radicals by excessive peroxide [10]. Similar to surfactant removal COD reduction improved with increasing of $\mathrm{H}_{2} \mathrm{O}_{2}$ dosage from $60 \%\left(\mathrm{H}_{2} \mathrm{O}_{2} / \mathrm{COD}=0.5\right)$ to $80 \%\left(\mathrm{H}_{2} \mathrm{O}_{2} / \mathrm{COD}=1.5\right)$. Further increase in $\mathrm{H}_{2} \mathrm{O}_{2} / \mathrm{COD}$ ratio to 1.75 resulted in reduction of the COD removal efficacy (see Fig. 1).

As it can be observed, this technique is not able to achieve the complete mineralization of the waste, and a percent of COD residual at the end of the treatment is around $15 \%$ (450 mg O $\mathrm{O}_{2} / \mathrm{dm}^{3}$ for $1 \mathrm{~g} / \mathrm{dm}^{3}$ initial Rokanol NL6 concentration). Similar conclusions were presented by Canizares and others [18]. According to their research these high concentrations of refractory carbon also appear in the Fenton oxidation of other kind of aqueous wastes [13] and seem to be characteristic of this oxidation process.

Another important point to consider in the Fenton oxidation is the amount of hydrogen peroxide required for efficient NL6 surfactant treatment when the surfactant concentration in the wastewater increases. The increase of surfactant concentration makes the emulsions more difficult to break, due to higher emulsion stability. The COD of such wastewater increases not only from greater amount of surfactant but also greater amount of residual oil.

Figure 2 shows the COD and NL6 removals for different initial surfactant concentration in the range between 1 and $5 \mathrm{~g} / \mathrm{dm}^{3}$. Figure 2 indicate that for Fenton process at $1.75 \mathrm{H}_{2} \mathrm{O}_{2} / \mathrm{COD}$ the optimum concentration of surfactant is around $3 \mathrm{~g} / \mathrm{dm}^{3}$. However, below and above $3 \mathrm{~g} / \mathrm{dm}^{3}$, the effect of $\mathrm{H}_{2} \mathrm{O}_{2} / \mathrm{COD}$ diminishes appreciably (after $1 \mathrm{~h}$ of 
Fenton oxidation). Below the $3 \mathrm{~g} / \mathrm{dm}^{3}$ concentration, the effect of $\mathrm{H}_{2} \mathrm{O}_{2} / \mathrm{COD}$ is quite strong (as mentioned above it may be caused by scavenging of hydroxyl radicals by excessive peroxide) and above the concentration the ratio is too small. The higher surfactant concentration was used the less COD was removed in comparison with the surfactant removal. It can indicate worse oil degradation (by 1-step Fenton process) in o/w emulsion stabilized by higher surfactant concentration. Hence, Fenton oxidation with $\mathrm{H}_{2} \mathrm{O}_{2} / \mathrm{COD}=1.75$ would be sufficient to realize over $85 \%$ COD and NL6 removal for wastewater with $3 \mathrm{~g} / \mathrm{dm}^{3}$ initial surfactant concentration.

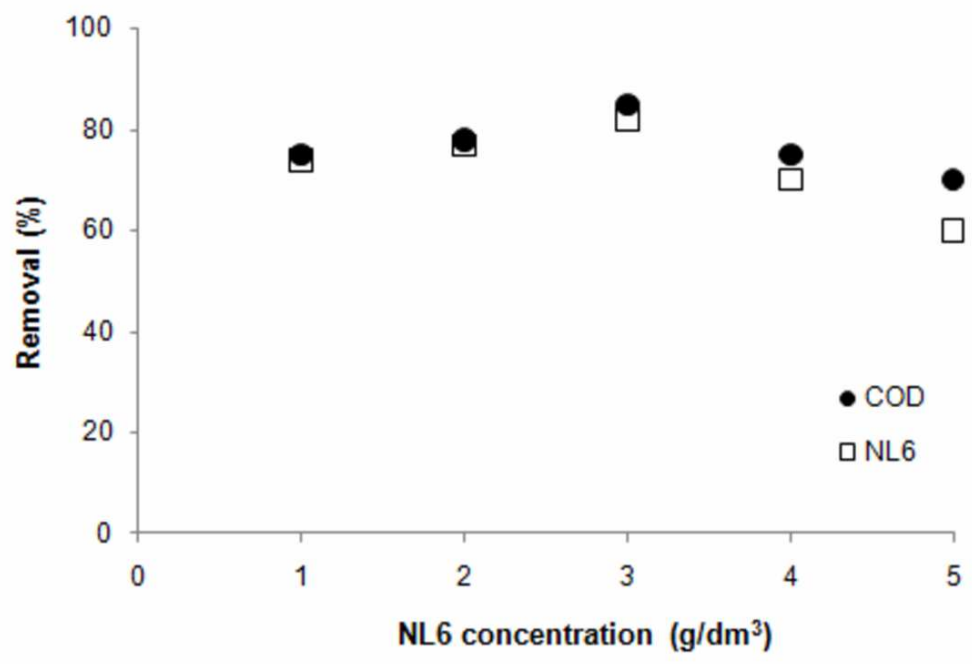

Fig. 2. Removal of COD and NL6 versus surfactant concentration for Fenton system at $1.75 \mathrm{H}_{2} \mathrm{O}_{2} / \mathrm{COD}$ weight ratio

From the results observed from here, the optimum operating conditions for the Fenton oxidation of NL6 would be $\mathrm{H}_{2} \mathrm{O}_{2} / \mathrm{COD}=1.5$. The optimum ratio of $\mathrm{H}_{2} \mathrm{O}_{2} / \mathrm{COD}$ concentrations at 1.5 is close to that (around 2) obtained in the previous studies by the authors $[12,13]$ despite the difference in the properties of wastewaters.

\section{Aerobic process 1-step}

In Figure 3 results of biological treatment of wastewater containing oil PAO6 and surfactant NL6 are presented. Again the COD values are proportional to the content of both components, while NL6 concentration presents the content of surfactant. After 3 hours of the process the COD removal was $28 \%$ and surfactant removal $35 \%$. The COD decreased gradually with time of treatment to $65 \%$ of removal after 5 hours of the process. The concentration of surfactant NL6 decreased rather slowly, and within 5 hours it diminished by $50 \%$. The Figure shows considerable improvement in treatment efficacy during the whole $6 \mathrm{~h}$ of biological treatment. Further increase in time, surely would enhance the efficiency of the process, however would be economically unjustified. 


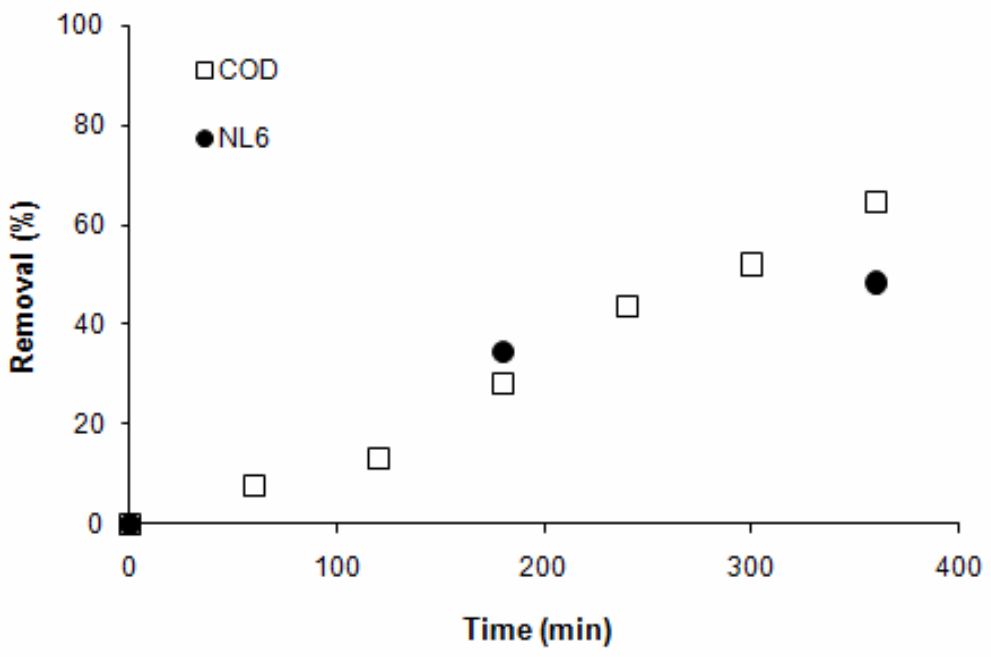

Fig. 3. Removal of COD and NL6 versus time during aerobic treatment at $1 \mathrm{~g} / \mathrm{dm}^{3}$ surfactant initial concentration

The aeration of the sludge during aerobic degradation of wastewater caused formation of enormous amounts of foam. Hence, it can be stated that the Rokanol NL6 surfactant was removed from wastewater mainly by defoaming mechanism. Vast amounts of foam generated in the reactor caused several problems like collecting the foam and its further treatment. So the additional step before aerobic treatment causing partial degradation of the surfactant would be useful. The efficiency of biological treatment alone was unsatisfactory. Thus in order to enhance the process more comprehensive strategies are needed like oxidation pretreatment step.

\section{Combined process 2-steps}

The degradation of wastewaters containing surfactant solution and stabilized $\mathrm{o} / \mathrm{w}$ emulsion was performed by the combined process constituted by Fenton process followed by an aerobic degradation. In the Fenton stage, two experiments were conducted in the reactor, by varying the $\mathrm{H}_{2} \mathrm{O}_{2} / \mathrm{COD}$ weight ratio (Fig. 4). For the Fenton pretreatment it can be seen a significant COD removal, in the range $75 \%$, which increases slightly when the $\mathrm{H}_{2} \mathrm{O}_{2} / \mathrm{COD}$ ratio is increased. Also, a significant removal of surfactant around $70 \%$ is observed which remains almost constant with the variation of the $\mathrm{H}_{2} \mathrm{O}_{2} / \mathrm{COD}$ ratio. As was mentioned previously, the surfactant present in these types of effluents constitutes an important limiting factor for using later biological treatments of these residues, since they are toxic to some types of bacteria and cause foaming. Thus, it can be expected that their elimination in this pretreatment should reduce the global toxicity of the effluent for a later biological treatment.

Once the Fenton pretreatment is finished, two corresponding aerobic degradation experiments were conducted with both effluents. Similarly to the 1-step processes, in this case the surfactant and the COD removals were followed during the treatment, and it was 
observed that both parameters decreased continuously with reaction time. It can be observed in this stage, reductions of surfactant in the range $95 \div 99 \%$ (see Fig. 4). While the COD removals are slightly lower, around $92 \%$, it is probably due to the significant degradation achieved in the Fenton pretreatment stage, which reduces considerably the remaining oil content for the aerobic stage.

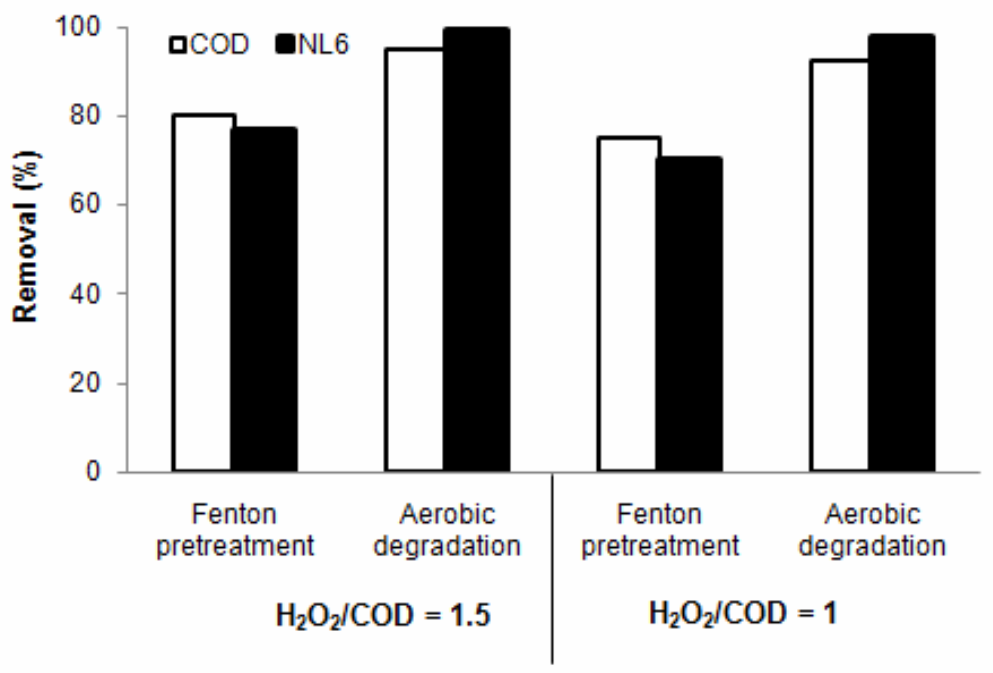

Fig. 4. Removal of COD and NL6 in combined chemical-biological process. Rokanol NL6 initial concentration $1 \mathrm{~g} / \mathrm{dm}^{3}$

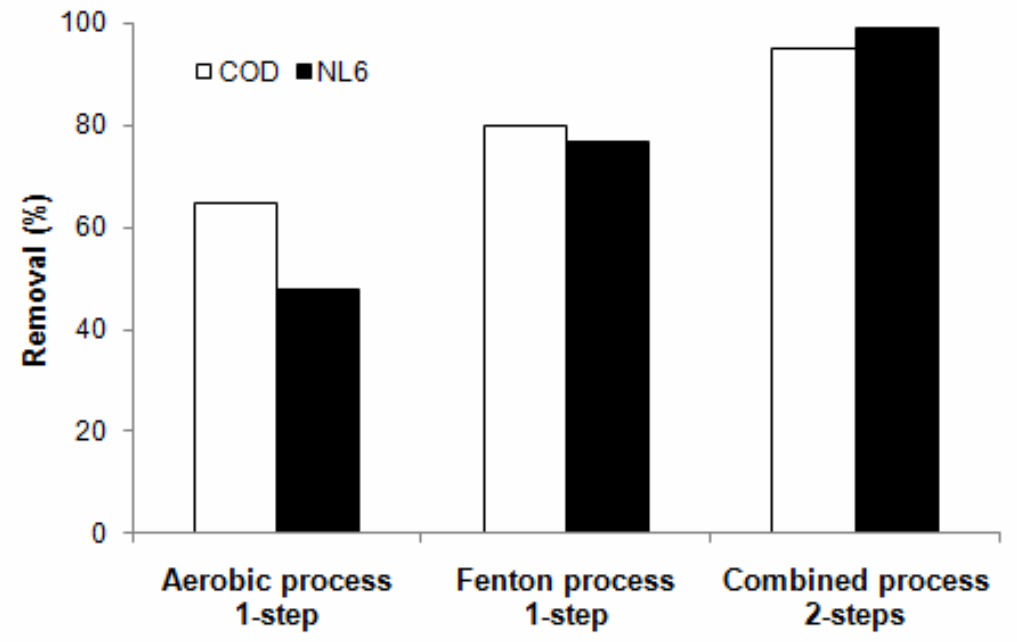

Fig. 5. Comparison of COD and NL6 removal in Fenton, aerobic and combined treatment. Rokanol NL6 initial concentration $1 \mathrm{~g} / \mathrm{dm}^{3}$ 
Also, from the results presented in Figure 5, the total reduction obtained for both parameters after the combined process can be evaluated: NL6 99\% and COD 95\%. It is seen that they are higher than the average values obtained in any 1-step treatments as could be expected, specially for the elimination of the surfactant. It demonstrates the efficiency of the combined process in the removal of the surfactant and oil rich wastewaters generated in the remediation of contaminated soil.

\section{Conclusions}

This investigation has looked into the feasibility of treating a surfactant solution and emulsified system stabilized by the addition of a non-ionic surfactant. In the single Fenton and aerobic degradation of investigated wastewaters, an average values of $80 \%$ and $65 \%$, respectively were obtained for the reduction of the both components measured as COD. Also $77 \%$ and $48 \%$ removal of the surfactant content were reached for Fenton and aerobic process respectively. In the combined process (Fenton pretreatment plus aerobic degradation treatment), global removals of $95 \%$ and $99 \%$ were obtained for the COD and NL6, much higher than those obtained in the single aerobic process. Therefore, the results obtained indicate a clear improvement in the parameters of the aerobic oxidation when a preoxidation stage is applied.

\section{Acknowledgements}

Financial support was provided by the Ministry of Science and Higher Education with grant N523 4411 33. We would also like to thank dr inż. S. Pastewski for his assistance.

\section{References}

[1] Lowe DF, Oubre CL, Ward CH. Surfactants and cosolvents for NAPL remediation. A technology practices manual. Boca Raton: Lewis Publishers; 1999.

[2] Mulligan CN, Yong RN, Gibbs BF: Eng Geol. 2001;60:371-380. DOI: 10.1016/S0013-7952(00)00117-4.

[3] Schramm LL. Emulsions, foams and suspensions. Weinheim: Wiley-VCH; 2005.

[4] Yoshimura K. J. Amer Oil Chem Soc. 1986;63:1590-1596. DOI: 10.1007/BF02553093.

[5] Aloui F, Kchaou S, Sayadi S. J Hazard Mat. 2009;164:353-359. DOI: 10.1016/j.jhazmat.2008.08.009.

[6] Prats D, Ruiz F, Vazquez B, Rodriguez-Pastor M. Water Res. 1997;31:1925-1930. DOI: $10.1016 / \mathrm{S} 0043-1354(97) 00040-7$.

[7] Neyens E, Baeyens J. J Hazard Mat. 2003;98:33-50. DOI: 10.1016/S0304-3894(02)00282-0.

[8] Palmroth MRT, Langwaldt JH, Aunola TA, Goi A, Puhakka JA, Tuhkanen TA. J Chem Technol Biotechnol. 2006;81:598-607. DOI: 10.1007/s10532-005-6060-3.

[9] Kallel M, Belaid C, Boussahel R, Ksibi M, Montiel A, Elleuch B: J Hazard Mater. 2008:163:550-554. DOI: 10.1016/j.jhazmat.2008.07.006.

[10] Kitis M, Adams CD, Daigger GT. Water Res. 1999;33:2561-2568. DOI: 10.1016/S0043-1354(98)00476-X.

[11] Lin SH, Lin CM, Leu HG. Water Res. 1999;33:1735-1741. DOI: 10.1016/S0043-1354(98)00403-5.

[12] Kulik N, Trapido M, Goi A, Veressinina Y, Munter R. Chemosphere. 2008;70:1525-1531. DOI: 10.1016/j.chemosphere.2007.08.026

[13] Trapido M, Kulik N, Veressinina Y, Munter R. Water Sci Technol. 2009;60:1795-1801. DOI: $10.2166 /$ wst.2009.585.

[14] Jeworski M, Heinzle E. Biotechnol Ann Rev. 2000;6:163-196. DOI: 10.1016/S1387-2656(00)06022-1.

[15] Pastewski S, Hallmann E, Mędrzycka K. Polish J Environ Stud. 2007;16:386-391.

[16] Tang WZ, Huang CP. Environ Technol. 1997;18:13-23.

[17] Kuo WG. Water Res. 1992;26:881-886. DOI: 10.1016/0043-1354(92)90192-7.

[18] Cañizares P, Lobato J, Paz R, Rodrigo MA, Sáez C. Chemosphere. 2007;67:832-838. DOI: 10.1016/j.chemosphere.2006.10.064. 


\title{
CHEMICZNO-BIOLOGICZNE OCZYSZCZANIE ŚCIEKÓW POWSTAJĄCYCH PODCZAS OCZYSZCZANIA ZAOLEJONYCH GRUNTÓW ROZTWORAMI SURFAKTANTÓW
}

\author{
${ }^{1}$ Katedra Technologii Tłuszczów i Detergentów, Wydział Chemiczny, Politechnika Gdańska
}

\begin{abstract}
Abstrakt: Ścieki powstające podczas procesu remediacji gruntu zawierają surfaktanty o wysokim stężeniu oraz oleje w postaci zemulgowanej i zsolubilizowanej lub wolnej. Do oczyszczenia takich ścieków zastosowano chemiczne utlenianie, biologiczne oczyszczanie oraz zintegrowany proces chemiczno-biologiczny. Efektywność procesu oceniono na podstawie redukcji ChZT oraz zmiany stężenia surfaktantu w oczyszczanych ściekach. Chemiczne utlenienie pozwoliło na $80 \%$ redukcję ChZT oraz stężenia surfaktantu w ściekach, w przypadku biologicznego oczyszczania parametry te zredukowano odpowiednio o $60 \%$ i $50 \%$. Jednak w zintegrowanym procesie biologiczno-chemicznym redukcja zarówno ChZT, jak i stężenia surfaktantu wyniosła ponad $90 \%$. Dlatego też chemiczne utlenienie może być stosowane jako wstępne oczyszczanie przed oczyszczaniem biologicznym w celu poprawy usunięcia zarówno ChZT, jak i surfaktantu w ściekach powstających podczas remediacji gruntów.
\end{abstract}

Słowa kluczowe: biologiczne oczyszczanie ścieków, chemiczne utlenianie, surfaktanty niejonowe, emulsja o/w, olej PAO6, remediacja gleby 